\title{
OPEN
}

\section{Author Correction: Bioprospecting desert plant Bacillus endophytic strains for their potential to enhance plant stress tolerance}

Ameerah Bokhari, Magbubah Essack $\mathbb{D}$, Feras F. Lafi $\mathbb{D}$, Cristina Andres-Barrao $\mathbb{D}$, Rewaa Jalal, Soha Alamoudi, Rozaimi Razali, Hanin Alzubaidy, Kausar H. Shah, Shahid Siddique $\mathbb{D}^{\text {, }}$ Vladimir B. Bajic $\mathbb{D}$, Heribert Hirt $\mathbb{D}$ \& Maged M. Saad (1)

Correction to: Scientific Reports https://doi.org/10.1038/s41598-019-54685-y, published online 03 December 2019

The original version of this Article omitted an affiliation for Rewaa Jalal. The correct affiliations for Rewaa Jalal are listed below:

King Abdullah University of Science and Technology (KAUST), Center for Desert Agriculture, Thuwal, 239556900, Kingdom of Saudi Arabia

University of Jeddah, P-O-BOX No.80327, Jeddah 21589, Saudi Arabia

This has now been corrected in the HTML and PDF versions of this Article, and in the accompanying Supplemental Material.

\begin{abstract}
(a) Open Access This article is licensed under a Creative Commons Attribution 4.0 International License, which permits use, sharing, adaptation, distribution and reproduction in any medium or format, as long as you give appropriate credit to the original author(s) and the source, provide a link to the Creative Commons license, and indicate if changes were made. The images or other third party material in this article are included in the article's Creative Commons license, unless indicated otherwise in a credit line to the material. If material is not included in the article's Creative Commons license and your intended use is not permitted by statutory regulation or exceeds the permitted use, you will need to obtain permission directly from the copyright holder. To view a copy of this license, visit http://creativecommons.org/licenses/by/4.0/.
\end{abstract}

(c) The Author(s) 2020 